\title{
INTEGRÁCIA CUDZINCOV (AZYLANTOV) V SLOVENSKEJ REPUBLIKE - PRÁVNE POSTAVENIE ${ }^{1}$
}

\author{
KLAUDIA MARCZYOVÁ
}

\begin{abstract}
Integration of Foreigners (Asylum Seekers) in the Slovak Republic - Legal Position
Integration, as a dynamic and bilateral process, requires not only the adaptation of foreign nationals to the new environment, but also the state must create conditions for that. It is an integral part of migration. These issues are addressed in the introductory part of the article. The paper also focuses on the legal aspects of the status of foreigners in the Slovak Republic in the context of the integration processes. The article includes an explanation of the so called law on aliens, selected aspects of the Act on Asylum, the Act on the Residence of Aliens, and the Act on Citizenship. The article also introduces the possibilities of enforcing certain rights which are part of the state's integration policy.
\end{abstract}

Keywords: aliens; foreign nationals; integration; migration; rights; asylum; residence of aliens; citizenship; integration policy; Constitution of the Slovak Republic

Klíčová slova: cudzinci; integrácia; migrácia; práva; azyl; pobyt cudzincov; štátne občianstvo; integračná politika; Ústava SR

DOI: $10.14712 / 23366478.2018 .10$

Migrácia ako fenomén, ako spoločenský jav má svoju históriu, a jej súčast'ou je viacero faktorov. Migrácia nie je novým javom, v istých časových obdobiach zaznamenávame aj intenzívnejšie migračné vlny ako dôsledok viacerých okolností. Migrácia výrazne ovplyvňuje politiku štátov, môže byt' zdrojom rozvoja (vyšší počet aktívnych produktívnych pracovníkov, platitel'ov daní, príspevkov do sociálnych fondov, zvýšená pôrodnost', ,príliv mozgov“, nové skúsenosti, zručnosti). Napr. v 20. storočí priniesla pre viaceré krajiny rozvoj, kedy najmä po druhej svetovej vojne migranti pomohli rastu ekonomiky, ale na druhej strane migrácia môže mat' aj dosah na negatívny ekonomický vývoj, a môže byt' aj zdrojom konfliktov. Je známe, že dôvody, ktoré motivujú l’udí k migrácii, sú rôzne, od chudoby, nízkej životnej úrovne, politickej nestability, za účelom štúdia, či zlúčenia rodiny až po hrozby živelných katastrof, ozbrojených konfliktov. Taktiež by sme mohli hovorit’ o tom, či ide o migráciu legálnu alebo nelegálnu. To všetko len nasvedčuje tomu, že skutočne ide o závažný spoločenský jav, s ktorým súvisí vel’a d’alších otázok a aspektov.

1 Príspevok je spracovaný v súvislosti s riešenou VVÚ 204/2014 na Akadémii Policajného zboru v Bratislave. 
V súčasnosti je jednou z klúčových otázok rezonujúcich európskym priestorom v nadväznosti na migráciu práve ochrana migrantov. Na medzinárodnej a regionálnej - európskej úrovni boli prijaté viaceré dokumenty, ktoré upravujú práva a slobody migrantov, garantujú ich základné práva. Či už poukážeme na viaceré z nich prijaté na pôde OSN v podobe všeobecných dokumentov zakotvujúcich základné práva a slobody ako Všeobecná deklarácia l'udských práv, alebo v podobe konkrétnejších, špecifických: Medzinárodný dohovor o odstránení všetkých foriem rasovej diskriminácie, Medzinárodný dohovor o ochrane práv všetkých migrujúcich pracovníkov a členov ich rodín, Dohovor o právnom postavení utečencov; taktiež prijaté Radou Európy: Dohovor o ochrane l'udských práv a základných slobôd, Európska sociálna charta, Európsky dohovor o právnom postavení migrujúcich pracovníkov, Dohovor o účasti cudzincov vo verejnom živote na miestnej úrovni. Aj Európska únia v tejto otázke vyvíja nemalé úsilie, a tak v posledných rokoch bolo prijatých viacero strategických dokumentov, ide najmä o Zmluvu o fungovaní Európskej únie, Chartu základných práv únie, Európsky pakt o prist’ahovalectve a azyle, Dublinský dohovor (nahradený Nariadením Rady (ES) č. 343/2003), Štokholmský program a Globálny prístup k migrácii.

Z hladiska právnej úpravy, ktorá sa dotýka postavenia a práv migrantov v Slovenskej republike, možno poukázat' na (a nielen) už uvádzané medzinárodné a európske dokumenty (ktorých výpočet však nie je definitívny), ale právny rámec ochrany migrantov predstavuje najmä vnútroštátna právna úprava zakotvujúca práva cudzincov, utečencov, ale vôbec aj oblast' základných práv a slobôd priznaných každej fyzickej osobe. Základnou zásadou predmetných dokumentov, ktoré garantujú základné práva a slobody je zákaz diskriminácie, ktorá je imanentnou súčast'ou aj vnútroštátnych predpisov Slovenskej republiky.

Tak ako je potrebná legislatívna úprava, zakotvenie práv cudzincov, je náležité aj nad’alej riešit súčasne i otázku integrácie cudzincov vo všetkých oblastiach. Aj postavenie migrantov v cudzej krajine so sebou nesie viacero aj negatívnych javov, dotýkajúcich sa priamo osoby migranta, či už riziko postavenia a prejavov nálad väčšinového obyvatel'stva, až po prejavy xenofóbie a rasizmu, frustrácia z cudzieho prostredia, iná kultúra, náboženstvo, zvyklosti a miera prispôsobenia sa týmto okolnostiam. Migranti sa často dostávajú do nerovnej pozície s väčšinovým obyvatel'stvom; v pracovných pozíciách, kedy nezastávajú kvalifikované miesto, nie sú akceptované diplomy o dosiahnutom vzdelaní. Súčastou integrácie cudzincov do spoločnosti je aj vytvorenie d’alších podmienok. Integrácia je dynamický a obojstranný proces, ktorý vyžaduje nielen prispôsobenie sa cudzincov v novom prostredí, ale aj vytvorenie podmienok zo strany štátu. Integračné opatrenia majú smerovat' k existencii nástrojov a opatrení, ktoré umožnia cudzincom predovšetkým:

- zaradit' sa na pracovný trh,

- zvládnut' výučbu slovenského jazyka,

- prístup ku vzdelaniu,

- prístup k zdravotnej starostlivosti,

- prístup k sociálnym službám,

- prístup k bývaniu a uznaniu kultúrnych špecifík,

- uznanie ich jasného právneho štatútu, účasti na občianskom a politickom živote, prípadne aj získanie štátneho občianstva SR. 
Ciel'om integračných aktivít je teda realizovat' také opatrenia, ktoré umožnia efektívnu integráciu cudzincov do spoločnosti za súčasného predchádzania negatívnych spoločenských javov, ako je rozdelenie spoločnosti a vzniku uzatvorených komunít migrantov.

Strategickým koncepčným dokumentom prijatým v Slovenskej republike v oblasti migrácie, ktorý sa stal zároveň východiskom pre budovanie modernej a ciel'avedomej migračnej politiky vlády SR je Migračná politika Slovenskej republiky s výhl'adom do roku 2020, uznesenie vlády Slovenskej republiky č. 574 z 31. augusta 2011. ,, Je jednoznačným vyjadrením pripravenosti a ochoty podiel'at's a na harmonizácii migračných politík jednotlivých štátov v rámci Európskej únie a výrazom spolupatričnosti kzákladným princípom a spôsobu jej fungovania pri riadení jednotlivých procesov migrácie. "2 Na jeho základe boli prijaté d'alšie opatrenia. Súčast’ou globálneho prístupu k migrácii je aj integračná politika, a je zároveň organickou súčast’ou migračnej politiky. Realizácia integračných aktivít je v Slovenskej republike vykonávaná v súlade s Koncepciou integrácie cudzincov v Slovenskej republike. Integračná politika SR (uznesenie vlády č. 45 z 29. januára 2014) nadväzuje na Koncepciu integrácie cudzincov v SR z roku 2009 (uznesenie vlády č. 338 zo 6. mája 2009) a vychádza z viacerých materiálov, ako aj smerníc Európskej únie. Základnými princípmi integračnej politiky sú princíp rovnosti, spravodlivosti a rešpektovania l’udskej dôstojnosti každého obyvatel'a krajiny. Integračná politika kladie dôraz na úlohy samospráv na miestnej a regionálnej úrovni, nakol'ko práve samosprávy pomáhajú integrácii cudzincov do spoločnosti, vytvárajú priestor na vzájomnú súdržnost' medzi majoritným obyvatel'stvom a cudzincami. Realizácia integračnej politiky vychádza zo vzájomnej koordinovanej spolupráce štátnych orgánov s orgánmi územnej samosprávy, miestnej štátnej správy a komunít cudzincov, vrátane spolupráce mimovládnych a iných organizácií, ktoré pôsobia v oblasti integrácie cudzincov.

V Slovenskej republike je gestorom migračnej politiky Ministerstvo vnútra Slovenskej republiky (d'alej aj ako „ministerstvo“).

Možno konštatovat', že v Slovenskej republike sa vyvíjajú viaceré aktivity smerujúcu k integrácii cudzincov, na ktorých participujú tak štátne orgány, orgány štátnej správy, orgány územnej samosprávy, ako aj viaceré organizácie a združenia. Existuje viacero projektov na podporu integrácie cudzincov v rôznych oblastiach spoločenského života. Pozornost' zasluhuje predovšetkým činnost' týchto inštitúcií: Medzinárodná organizácia pre migráciu, Migračné informačné centrum Medzinárodnej organizácie pre migrácius pobočkami v Bratislave a v Košiciach (informačné centrum, ktoré na jednom mieste poskytuje cudzincom komplexné služby v oblasti právneho, sociálneho a pracovného poradenstva, d’alšieho vzdelávania, inklúzie na trh práce a podpory komunitného života cudzincov), ${ }^{3}$ Migračný úrad MV SR, Úrad vysokého komisára pre utečencov (UNHCR), Inštitút pre verejné otázky (IVO), Centrum pre výskum etnicity a kultúry (CVEK), Liga za l'udské práva. Taktiež je potrebné vyzdvihnút' význam a úlohy obcí v oblasti integrá-

2 Migračná politika Slovenskej republiky s výhl’adom do roku 2020, s. 3, dostupné na : https://www.minv .sk/?zamer-migracnej-politiky-slovenskej-republiky.

3 Súhrnná správa o stave plnenia ciel’ov a opatrení Integračnej politiky Slovenskej republiky za rok 2016, apríl 2017, s. 4. 
cie cudzincov, ktoré vytvárajú priestor pre komunikáciu s verejnými inštitúciami, plnia úlohu v oblasti informovania, poskytujú verejné služby, sociálne služby a kultúrne aktivity, ako aj vzdelanie. Nezastupitel'nú úlohu plnia aj v prípade implementácie programov, ktoré sa realizujú v prostredí, kde migranti žijú.

Pre vytýčenie priznaných práv cudzincom je potrebné určit právny status migranta; či ide o legálnych, nelegálnych migrantov, azylantov, žiadatel'ov o azyl, osoby s doplnkovou ochranou, čo je determinujúce aj pre určenie rozsahu priznaných d'alších konkrétnych práv a slobôd.

Základnou vnútroštátnou právnou normou, ktorá zaručuje základné práva a slobody, je Ústava Slovenskej republiky. V zmysle čl. 52 ods. 2 Ústavy „Cudzinci požívajú v Slovenskej republike základné l'udské práva a slobody zaručené touto ústavou, ak nie sú výslovne priznané iba občanom. " a upravuje exkluzívne právo zaručené iba cudzincom - právo na azyl. ,,Slovenská republika poskytuje azyl cudzincom prenasledovaným za uplatñovanie politických práv a slobôd. Azyl možno odopriet tomu, kto konal v rozpore so základnými l'udskými právami a slobodami. Podrobnosti ustanoví zákon. " "Uvedený článok možno interpretovat'v kontexte s medzinárodnými dohovormi (čl. 154c ods. 1 Ústavy SR), a taktiež vo vzt'ahu k subjektu - nositel'a práva na azyl použit' extenzívny výklad. Znamená to, že napriek ústavnému vymedzeniu - poskytuje azyl cudzincom, vzt’ahuje sa uplatnenie tohto práva aj na osoby bez štátnej príslušnosti (bezdomovcov, apolitov). „Právo na azyl sa priznáva v rozsahu dvoch kumulatívnych podmienok. Prvou podmienkou je prenasledovanie, druhou podmienkou je uplatnenie politických práv a slobôd. "5 Vyžaduje sa súvislost' medzi prenasledovaním a uplatnením práv. Účelom práva na azyl je poskytnutie ochrany osobe, ktorá je prenasledovaná za uplatňovanie politických práv a slobôd, pričom stačí prenasledovanie za uplatnenie jedného práva alebo slobody. Jednou z riešených otázok je, či dôvody, pre ktoré jednotlivec žiada o poskytnutie azylu sú relevantné, ktoré situácie sú prenasledovaním. Za prenasledovanie v kontexte s podstatou azylu nemožno považovat' chudobu, resp. ekonomické dôvody. ,Základnou a všeobecne uznávaným zmyslom a účelom azylového práva je zaručit toto právo cudzincovi, ktorý už nemôže d'alej žit' vo vlastnej krajine, pretože jej politický systém ho pozbavuje slobody, života alebo majetku. "6 Uplatnenie práva na azyl oprávnenou osobou zakladá povinnost' Slovenskej republiky rozhodnút', či azyl poskytne. Právo na azyl sa priznáva každej osobe - cudzincovi, ktorá spíña ústavou určenú podmienku; to znamená, že z daného ustanovenia nevyplýva absolútne právo na azyl: ,, nie je možné odvodit’ záver, že cudzinec má , absolútne ' a ničím neobmedzené právo na poskytnutie azylu, nakol'ko jeho priznanie možno odopriet' tomu, kto konal v rozpore so základnými ludskými právami a slobodami “.7 V prípade, ak ,,osoba, ktorá voči Slovenskej republike uplatñuje právo na azyl, nekonala v rozpore so základnými l'udskými právami a slobodami, azyl jej nemožno odopriet'. Dokonca ani splnenie $v$ Ústave určenej podmienky nevylučuje poskytnutie azylu. Dôkazné bremeno o tom, že uchádzač o azyl konal v rozpore so základnými l’udskými právami a slobodami, sa

\footnotetext{
Čl. 53 Ústavy Slovenskej republiky.

ČIČ, M. a kol.: Komentár k Ústave Slovenskej republiky. Žilina, 2012, s. 367.

BRÖSTL, A. a kol.: Ústavné právo Slovenskej republiky. Plzeň, 2013, s. 177.

Uznesenie ÚS SR z 19. februára 1998, sp. zn. ÚS 12/98.
} 
prenáša zo záujemcu o azyl na Slovenskú republiku. “8 Obsahom, možno povedat' vzhl’adom na svoje historické korene, ${ }^{9}$ tohto tradičného práva, nie je získat' azyl, ale uchádzat' sa o azyl. V medzinárodnom práve sa azylové právo chápe ako výlučné právo suverénneho štátu voči iným štátom zaručovat' osobám, ktoré nemajú jeho štátnu príslušnost' a sú z určitých dôvodov prenasledované, ochranu a útočisko na svojom území, ak tomu nebránia obmedzenia vyplývajúce z medzinárodných zmlúv. ${ }^{10}$

Vykonávacím zákonom, za akých podmienok sa môže cudzinec na území Slovenskej republiky domáhat' poskytnutia azylu, je zákon č. 480/2002 Z. z. o azyle a o zmene a doplnení niektorých zákonov v znení neskorších predpisov. Zákon o azyle je (spolu so zákonom o pobyte cudzincov) najdôležitejším zákonom upravujúcim postavenie cudzinca, a od svojho prijatia prešiel istými zmenami, ktoré si vynútili aj spoločenské okolnosti, záujem bezpečnosti krajiny, ako aj transpozícia európskych smerníc.

Zákon o azyle upravuje konanie o udelení azylu; postup pri poskytovaní dočasného útočiska; práva a povinnosti žiadatel'ov o udelenie azylu, azylantov, cudzincov, ktorým sa poskytla doplnková ochrana, cudzincov žiadajúcich o poskytnutie dočasného útočiska a odídencov; pôsobnost' orgánov verejnej moci na úseku azylu, doplnkovej ochrany a dočasného útočiska; ale upravuje aj integráciu azylantov do spoločnosti a pobyt v azylových zariadeniach. Vo svojej druhej hlave upravuje aj spôsoby zániku azylu, ako aj konanie o odňatí azylu, ktoré sa začína z podnetu ministerstva, či zrušenie doplnkovej ochrany. Zákon d'alej upravuje v tretej časti Práva a povinnosti žiadatel'ov, azylantov a cudzincov, ktorým sa poskytla doplnková ochrana. Vo všeobecnosti platí, že osoba, ktorá žiada o udelenie azylu je bez peňažných prostriedkov, a tak je na strane prijímajúceho štátu, aby jej zabezpečil základné potreby nevyhnutné pre život. Žiadatel’ovi o azyl sa v zmysle zákona o azyle poskytuje v azylovom zariadení alebo integračnom stredisku strava, vreckové, základné hygienické a iné veci potrebné na prežitie. Azylant sa považuje za cudzinca, ktorému sa udelil trvalý pobyt na území SR. Azylantom sa osoba stáva až okamihom rozhodnutia o udelení azylu. Ministerstvo môže azylanta na základe jeho písomnej žiadosti na nevyhnutný čas ubytovat' v pobytovom tábore, kde je povinný primerane uhrádzat' výdavky spojené s jeho pobytom. Azylant je povinný spolupracovat's ministerstvom a d'alšími orgánmi pri jeho integrácii, dodržiavat' vnútorný poriadok v tábore, oznámit' ministerstvu narodenie diet’ata, či udelenie štátneho občianstva. V Slovenskej republike sú zriadené pobytové tábory v Opatovskej Novej Vsi s kapacitou 140 miest a v Rohovciach tiež s kapacitou 140 miest, a v Humennom je zriadený záchytný tábor (kapacita 550 miest). Žiadatelia o azyl sa zdržiavajú v záchytnom tábore približne 21 až 30 dní, čo je čas nevyhnutne potrebný na vykonanie vstupnej lekárskej prehliadky, zistenie prípadných cudzokrajných ochorení z dôvodu ochrany obyvatel'ov na Slovensku. Po ukončenej prehliadke a prvom pohovore so žiadatel'om o azyl sú presúvaní do pobytových táborov migračného úradu, kde sa zdržiavajú až do

\footnotetext{
8 DRGONEC, J.: Ústava Slovenskej republiky. Bratislava, 2015, s. 997.

9 História a vývoj azylu sa spája so vznikom prvých štátov v staroveku. Pôvodne bol azyl náboženským inštitútom, a každý, kto sa uchýlil na posvätnom mieste bol chránený pred svetským násilím. V neskoršom období sa formuje právny inštitút azylu, ktorý súvisí s utečeneckou problematikou, odvíja sa od občianskych vojen, prenasledovania z dôvodu vierovyznania, rasy, politického zmýšl'ania.

10 BRÖSTL, A. a kol.: Ústavné právo Slovenskej republiky. Plzeň, 2013, s. 177.
} 
času právoplatného ukončenia konania o udelení azylu, o ktorom sa rozhodne $\mathrm{v}$ lehote do 90 dní (v prípade nutnosti je možné lehotu predížit'). Nielenže je v tábore cudzincom poskytovaná strava, ubytovanie, zdravotná starostlivost', či psychologické poradenstvo, ale poskytuje sa im aj základný kurz slovenského jazyka, čo je nevyhnutnou súčast'ou úspešnej integrácie cudzinca. Na dlhší čas sú v tomto tábore umiestňovaní cudzinci so štatútom utečenca.

Postupné začleňovanie azylantov do spoločnosti je dlhodobý a náročný proces. Hlavným ciel'om integrácie je úplná sebestačnost' a nezávislost' azylantov. Integrácia vyžaduje aktívnu podporu nielen štátu, ale aj d'alších subjektov. Obsahom štvrtej časti zákona o azyle je integrácia, upravená v $§ 28, \mathrm{v}$ zmysle ktorého je ciel’om integrácie začlenenie azylantov do spoločnosti, najmä získanie vhodného ubytovania a zamestnania. „Po udelení azylu ministerstvo azylanta spravidla umiestni v integračnom stredisku. " 11 Pobyt v integračnom stredisku je akousi prípravou azylanta na samostatný pobyt v cudzej krajine. Na Slovensku sa integračné stredisko nachádza vo Zvolene, $\mathrm{s}$ kapacitou 12 bytov. Po skončení pobytu $\mathrm{v}$ integračnom stredisku, kde je zabezpečený pobyt maximálne na 6 mesiacov, a v prípade nutnosti možnost' predížit' o tri mesiace, a po absolvovaní kurzu základov slovenského jazyka ministerstvo ponúkne azylantovi jednorazovo možnost' ubytovania. Ministerstvo poskytne obci, ktorá zabezpečí azylantovi ubytovanie, príspevok na zaobstaranie ubytovania alebo príspevok na rozvoj infraštruktúry obce za podmienok určených komplexným programom integrácie, ktorý na návrh ministerstva schval'uje vláda. Z piateho odseku uvedeného paragrafu vyplýva, že azylant je na ul'ahčenie integrácie do spoločnosti povinný počas pobytu $\mathrm{v}$ integračnom stredisku navštevovat' kurz základov slovenského jazyka (zabezpečuje ministerstvo). Ministerstvo na žiadost' zabezpečí kurz základov slovenského jazyka aj azylantovi, ktorý nebol umiestnený $\mathrm{v}$ integračnom stredisku alebo ktorý počas pobytu $\mathrm{v}$ integračnom stredisku neabsolvoval kurz základov slovenského jazyka.

Konanie o udelení azylu začína vyhlásením cudzinca na príslušnom policajnom útvare, že žiada o udelenie azylu alebo o poskytnutie doplnkovej ochrany na území Slovenskej republiky. Z dikcie zákona vyplýva, že Ministerstvo vnútra Slovenskej republiky udelí azyl žiadatel’ovi, (ak zákon neustanovuje inak), ktorý:

- má v krajine pôvodu opodstatnené obavy z prenasledovania z rasových, národnostných alebo náboženských dôvodov, z dôvodov zastávania určitých politických názorov alebo príslušnosti $\mathrm{k}$ určitej sociálnej skupine a vzhl'adom na tieto obavy sa nemôže alebo nechce vrátit' do tohto štátu, alebo

- je v krajine pôvodu prenasledovaný za uplatňovanie politických práv a slobôd.

Ministerstvo vnútra Slovenskej republiky môže udelit' azyl aj z humanitných dôvodov (dôvodov hodných osobitného zretel'a, napr. vel'mi zlý zdravotný stav žiadatel'a, t’ažká trauma či vysoký vek, ktoré by pri jeho návrate do krajiny pôvodu pre neho mohli predstavovat' vážne riziko), či na účel zlúčenia rodiny - manželovi azylanta, ak manželstvo trvá a trvalo aj v čase, ked' azylant odišiel z krajiny pôvodu a azylant so zlúčením vopred písomne súhlasí; slobodným det’om azylanta; rodičom slobodného

$11 \S 28$ ods. 2 zákona č. 480/2002 Z. z. o azyle a o zmene a doplnení niektorých zákonov v znení neskorších predpisov. 
azylanta mladšieho ako 18 rokov alebo osobe, ktorej bol zverený do osobnej starostlivosti, ak s tým azylant vopred písomne súhlasí. Takíto žiadatelia sa počas konania o udelenie azylu musia zdržiavat' na území Slovenskej republiky a nesmú mat' na území Slovenskej republiky udelený trvalý pobyt podl’a osobitného zákona. ${ }^{12}$ Základným predpokladom poskytnutia ochrany práva na azyl je vyhlásenie cudzinca o tom, že žiada o priznanie azylu. Uplatnenie práva oprávnenou osobou zakladá povinnost' štátu rozhodnút', či azyl poskytne. Je na rozhodnutí štátu, komu azyl poskytne, ale na druhej strane treba poznamenat', že vôl'a štátu nie je neobmedzená, ked’že z dikcie ústavy vyplýva, že azyl možno odopriet' tomu, kto konal v rozpore so základnými l'udskými právami a slobodami. ${ }^{13}$

V prípade neudelenia azylu žiadatel'ovi o azyl, slúži na účely rešpektovania zásady non-refoulement inštitút poskytovania doplnkovej ochrany. Jeho zmyslom je poskytnút' subsidiárnu ochranu a možnost' legálneho pobytu na našom území osobám, ktorým nebol udelený azyl, ale ich návrat do krajiny pôvodu je neúnosný. Zákon upravuje aj inštitút poskytnutia dočasného útočiska, ale aj oblast' spolupráce s úradom vysokého komisára, medzinárodnou organizáciou pre migráciu a mimovládnymi organizáciami.

V rámci medzinárodnej ochrany cudzincov Slovenská republika poskytuje ochranu vo forme azylu a doplnkovej ochrany. Podstatným rozdielom pri udel'ovaní azylu a poskytovaní doplnkovej ochrany je čas, na ktorý sa ochrana udel'uje. V prípade azylu ide o trvalý pobyt cudzinca na území SR (okrem azylu udeleného na účel zlúčenia rodiny, kedy sa azyl prvýkrát udel'uje na tri roky a až po uplynutí troch rokov sa azyl na základe žiadosti udelí na dobu neurčitú).

Napriek zmenám v zákone o azyle nad’alej zostali rozdiely medzi právami a výhodami, ktoré majú cudzinci s udeleným azylom a cudzinci s poskytnutou doplnkovou ochranou, čo je viditel'né najmä pri integračných opatreniach - zodpovednost' za integráciu azylantov má štát, pričom cudzincom s poskytnutou doplnkovou ochranou zabezpečujú integráciu mimovládne organizácie.

Zo Smernice Európskeho parlamentu a Rady 2013/33/EÚ z 26. júna 2013, ktorou sa stanovujú normy pre prijímanie žiadatel'ov o medzinárodnú ochranu, vyplýva povinnost' zabezpečit’ primeranú životnú úroveň, v súvislosti s poskytovaním ubytovania, dbat' o to, aby boli rodiny spoločne, poskytnút' vzdelávanie v pobytových táboroch, umožnit' prístup k vzdelávaciemu systému, zapojit' ženy - žiadatel'ky o azyl do programov odbornej prípravy s ciel'om prelomit' izoláciu, zlepšit' ich postavenie a nezávislost', podporit' znalost' miestnych zvyklostí a každodenného života, čím sa obnoví ich pocit rovnosti, spolupatričnosti a sebaúcty.

Migračný úrad MV SR je prvostupňový správny orgán rozhodujúci o udel'ovaní azylu a poskytnutí doplnkovej ochrany. Odbor migrácie a integrácie najmä:

- spolupracuje so zainteresovanými orgánmi štátnej správy, samosprávy a mimovládnymi organizáciami na integrácií azylantov do spoločnosti najmä v oblasti ubytovania, zamestnania, sociálneho zabezpečenia a vzdelávania, (Ministerstvo školstva, vedy, výskumu a športu Slovenskej republiky, Štátna školská inšpekcia, Ministerstvo

12 Zákon č. 404/2011 Z. z. o pobyte cudzincov a o zmene a doplnení niektorých zákonov v znení neskorších zmien a doplnkov.

13 ČIČ, M. a kol.: Komentár k Ústave Slovenskej republiky. Žilina, 2012, s. 367. 
práce, sociálnych vecí a rodiny Slovenskej republiky), dohliada na vzdelávanie maloletých žiadatel'ov o udelenie azylu,

- vykonáva kontrolu projektov financovaných zo zdrojov Európskej únie v oblasti starostlivosti o žiadatel'ov o udelenie azylu, azylantov a cudzincov, ktorým sa poskytla doplnková ochrana,

- metodicky riadi, usmerňuje a kontroluje vykonávanie sociálnej práce v azylových zariadeniach,

- spolupracuje s príslušnými útvarmi ministerstva a mimovládnymi organizáciami pri realizácii projektov financovaných z prostriedkov Európskej únie,

- zabezpečuje vypracovanie návrhov „,národných projektov“ migračného úradu v rámci Fondu pre azyl, migráciu a integráciu, zabezpečuje ich koordináciu a realizáciu,

- koordinuje spoluprácu v oblasti príjmu utečencov, najmä v rámci Európskej siete azylových organizácií pracujúcich v oblasti príjmu utečencov (ENARO),

- realizuje aktivity súvisiace s činnost’ou národného kontaktného bodu Európskej migračnej siete $(\mathrm{EMN}) .^{14}$

V súvislosti s praktickou stránkou možno poukázat' na niektoré problémy, ktoré sa najčastejšie vyskytujú pri udel’ovaní azylu, a to napr. nedostatok dôkazných prostriedkov pri udel’ovaní azylu a ich zadováženie; často chýbajúce doklady totožnosti; jazyková bariéra a nepochopenie podstaty pohovoru žiadatel'ov či overovanie originality listinných dôkazov. Nevýhodou sú aj nedostatočné kapacity na preverenie dokladov, prípadne aj v neúplných, nesprávnych informáciách o krajine pôvodu (pochybenie zo strany migračného úradu). Aj napriek tomu však možno konštatovat', že konanie o udelení azylu je v SR v podstate bezpriet’ahové.

Postavenie cudzincov upravuje taktiež zákon č. 404/2011 Z. z. o pobyte cudzincov a o zmene a doplnení niektorých zákonov v znení neskorších predpisov. Zákon vymedzuje i pojem cudzinec - je ním každý, kto nie je štátnym občanom SR. Avšak v širšom poňatí môžeme hovorit' o každej fyzickej osobe, ktorá nie je občanom daného štátu, teda aj osoby bez štátneho občianstva (apoliti, bezdomovci). V užšom poňatí rozumieme cudzincom iba osobu, ktorá sa nachádza $\mathrm{v}$ danej krajine a ktorá má štátnoobčiansky vzt'ah k inému štátu. Cudzincov na území Slovenskej republiky môžeme rozdelit’ na cudzincov pochádzajúcich z členských štátov EÚ alebo zo štátov mimo EÚ, bezvízoví a vízoví, cudzinci na základe špeciálnych udalostí (napríklad utečenci, imigranti) a cudzinci so špeciálnym medzinárodným statusom (diplomati, konzuli). V tretej časti zákon upravuje Pobyt cudzincov: ,,Prechodný pobyt oprávňuje štátneho prislušníka tretej krajiny zdržiavat' sa, vycestovat' a opätovne vstupovat' na územie Slovenskej republiky $v$ čase, na aký mu bol policajným útvarom udelený. "15 Je viazaný na jeden účel, pričom prechodný pobyt možno udelit' pre účely podnikania (na čas potrebný na podnikanie, najviac na 3 roky), zamestnania (na čas potrebný, najviac na 5 rokov), štúdia (na čas potrebný na štúdium, najviac na 6 rokov), osobitnej činnosti, výskumu a vývoja a zlúčenia rodiny, na účel plnenia služobných povinností civilnými zložkami ozbrojených síl, osobe, ktorá má priznané postavenie zahraničného Slováka, ako aj tomu, kto má priznané

14 Dostupné na: https://www.minv.sk/?odbor-migracie-a-integracie.

15 § 20 ods. 1 zákona č. 404/2011 Z .z. o pobyte cudzincov a o zmene a doplnení niektorých zákonov v znení neskorších zmien a doplnkov. 
postavenie osoby s dlhodobým pobytom $\mathrm{v}$ inom členskom štáte. Trvalý pobyt oprávňuje štátneho príslušníka tretej krajiny zdržiavat' sa, vycestovat' a opätovne vstupovat' na územie Slovenskej republiky v čase, na ktorý mu bol policajným útvarom udelený, ak tento zákon neustanovuje inak, pričom môže byt' udelený na 5 rokov, ale aj na neobmedzený čas. Zákon upravuje aj podmienky udelenia tolerovaného pobytu, ako aj osobitne udel'ovanie pobytu pre občanov EÚ a jeho rodinného príslušníka, ako aj d'alšie otázky.

Ďalšou právnou normou, ktorá do istej miery upravuje, završuje po formálnej stránke proces integrácie cudzincov, je zákon č. 40/1993 Z. z. o štátnom občianstve Slovenskej republiky v znení neskorších predpisov. Zámerne bol použitý výraz - po formálnej stránke, pretože ani udelením štátneho občianstva SR, nemožno hovorit’ o tom, že by bol proces integrácie ukončený. $\mathrm{V}$ tomto prípade dochádza $\mathrm{k}$ podstatnej zmene statusu jednotlivca, ked’že štátne občianstvo umožňuje ovel’a širší rozsah uplatňovania základných práv a slobôd, ako v prípade cudzincov. Štátne občianstvo možno vymedzit' ako politicko-právny zväzok medzi fyzickou osobou a štátom, a aj ako osobný právny pomer určitej fyzickej osoby $\mathrm{k}$ určitému štátu bez ohl'adu k podobnému faktickému pomeru založenému pobytom alebo bydliskom v danom štáte. Spôsoby nadobúdania štátneho občianstva SR upravuje zákon o štátnom občianstve, kde jedným zo spôsobov nadobúdania štátneho občianstva SR je udelenie štátneho občianstva cudzincovi (bezdomovcovi) na základe vlastnej žiadosti. Štátne občianstvo možno udelit' osobe, ktorá nie je štátnym občanom SR a ktorá spíňa zákonom stanovené podmienky, ako napr. to, že má nepretržitý trvalý pobyt na území Slovenskej republiky aspoň osem rokov bezprostredne predchádzajúcich podaniu žiadosti; je bezúhonná; nebol jej súdom uložený trest vyhostenia; nie je proti nej vedené trestné stíhanie; nie je proti nej vedené vydávacie konanie ani konanie o vykonaní európskeho zatýkacieho rozkazu; nie je proti nej vedené konanie o administratívnom vyhostení; nie je proti nej vedené konanie o odňatí azylu; preukáže, že ovláda slovenský jazyk a plní si povinnosti vyplývajúce pre cudzincov z ustanovení právnych predpisov SR (ako pobyt cudzincov na území SR, sociálne poistenie a d'alšie). Určená podmienka trvalého pobytu sa nevzt'ahuje na prípady, napr. ak má žiadatel' povolený pobyt a

- uzavrel manželstvo so štátnym občanom Slovenskej republiky a žije v tomto manželstve v spoločnej domácnosti na území SR aspoň pät’ rokov bezprostredne predchádzajúcich podaniu žiadosti o udelenie štátneho občianstva Slovenskej republi$\mathrm{ky}$,

- ide o osobu, ktorá sa významne zaslúžila o prínos pre Slovenskú republiku v oblasti ekonomickej, vedeckej, kultúrnej, technickej, sociálnej, športovej alebo z iného dôvodu v záujme SR,

- má na území SR nepretržitý trvalý pobyt začínajúci najmenej tri roky pred dosiahnutím 18 rokov veku,

- je azylantom aspoň štyri roky bezprostredne predchádzajúce podaniu žiadosti,

- sa narodil na území SR a má tu trvalý pobyt najmenej tri roky bezprostredne predchádzajúce podaniu žiadosti o udelenie štátneho občianstva Slovenskej republiky,

- má na území SR nepretržitý pobyt najmenej desat' rokov a v čase podania žiadosti mu už bolo udelené povolenie na trvalý pobyt, 
- je bez štátnej príslušnosti a má na území SR nepretržitý pobyt najmenej tri roky bezprostredne predchádzajúce podaniu žiadosti o udelenie štátneho občianstva Slovenskej republiky,

- bol prepustený zo štátneho zväzku Slovenskej republiky podl’a § 9 zákona o štátnom občianstve SR a má na území Slovenskej republiky nepretržitý pobyt najmenej dva roky bezprostredne predchádzajúce podaniu žiadosti o udelenie štátneho občianstva Slovenskej republiky,

- ide o osobu, ktorej bolo vydané osvedčenie preukazujúce postavenie Slováka žijúceho v zahraničí, ${ }^{16}$ ak má nepretržitý pobyt na našom území najmenej tri roky.

V roku 2016 bolo udelené štátne občianstvo SR v 399 prípadoch, z toho napr. žiadatel'om z Ukrajiny v počte 91,75 - Česká republika a 67 - Srbsko.

Slovenská republika, aj napriek určitému nárastu počtu migrantov je stále krajinou s nízkym (najnižším) počtom migrantov v Európskej únii. V súčasnosti už nie je len tranzitnou krajinou, ale vzhl’adom aj na istý rozmach ekonomiky stáva sa ciel'ovou krajinou niektorých migrantov. Nárast spôsobila aj celková situácia v Stredomorí a zvýšený počet migrantov a utečencov smerujúcich do Európy, čo však prináša aj tragické udalosti. V roku 2015 ,,sa na slovensko-rakúskych hraniciach stala tragédia, ked’v prevádzačskej dodávke zahynulo 71 utečencov ". ${ }^{17}$

V roku 2004 sme zaznamenali prípady, kedy migranti chceli využit’ tranzit cez Slovensko, dochádzalo $\mathrm{k}$ zneužitiu azylového konania z dôvodu zlegalizovania svojho pobytu na území SR a následnej prípravy na nelegálny vstup do tretieho štátu, s ciel’om dostat' sa do ekonomicky vyspelejšej krajiny. Najväčšie skupiny migrantov pochádzajú najmä z Ukrajiny, Rumunska, Bulharska, Srbska, Ruska, ale aj z juhovýchodnej Ázie (Vietnam, Č́na) a Kórei.

Pre názornost' uvádzame nasledovné údaje:

- cudzinci s povoleným pobytom v SR - 97934

- tvoria na celkovej populácii obyvatel'stva 1,8 \% (menej: Bulharsko, Chorvátsko, Lit-

va, Rumunsko a Pol'sko)

- občania EÚ - $\mathbf{5 4 , 3} \%$, z toho ČR - 10,7 \%

- zamestnaných - $\mathbf{4 2}$ 387, z toho mimo EÚ - 15846

- na 60 domácich zamestnancov - 1 pracujúci cudzinec. ${ }^{18}$

Ako už bolo uvedené, integračná politika sa zameriava najmä na základné oblasti zabezpečenia potrieb pre každodenný život. Primárnou ciel'ovou skupinou integrácie sú legálni migranti, osoby s udeleným dlhodobým, trvalým pobytom a azylanti. Jednou z oblastí v rámci integračnej politiky je aj prístup $\mathbf{k}$ bývaniu. V SR je zodpovednost' za zaobstaranie si bývania prenechaná v prvom rade na občana, avšak SR vytvára možnosti prístupnosti ku bývaniu aj pre znevýhodnené skupiny, ktorými sú aj cudzinci a migranti, a tak sú možnými žiadatel'mi o pridelenie nájomného bytu určeného na sociálne bývanie, ktoré poskytujú obce a mestá. Z Koncepcie štátnej bytovej politiky SR do roku 2020 vyplýva, že je prvoradou úlohou štátu vytvorit’ rovnaké východiskové podmienky

16 Zákon č. 474/2005 Z. z. o Slovákoch žijúcich v zahraničí a o zmene a doplnení niektorých zákonov.

17 NOVÁKOVÁ, I.: Obraz polície v mediálnom diskurze o migrácii. In ŠTEFANČ́́K, R.: Jazyk a politika. Na pomedzi lingvistiky a politológie II. Bratislava, 2017, s. 350.

18 Spracované k júnu 2017. Zdroj: www.iom.sk. 
pre vstup na trh s bývaním pre všetkých, a tak je umožnené príslušníkom z tretích krajín napr. získanie výhodného úveru na bývanie.

V SR sa det’om poskytuje vzdelanie rovnako ako občanom, v štátnych školách zadarmo. Podl'a zákona č. 245/2008 Z. z. o výchove a vzdelávaní (školský zákon) a o zmene a doplnení niektorých zákonov v znení neskorších predpisov sa cudzincami rozumejú deti:

- osôb, ktoré sú občanmi iného štátu alebo osôb bez štátnej príslušnosti, s povoleným pobytom na území Slovenskej republiky,

- žiadatel’ov o udelenie azylu na území Slovenskej republiky podl’a osobitného predpisu,

- Slovákov žijúcich v zahraničí,

- ako žiadatelia o azyl (doplnkovú ochranu) podl'a osobitného predpisu,

- ako cudzinci, ktorí sa nachádzajú na území Slovenskej republiky bez sprievodu zákonného zástupcu.

Pre deti cudzincov sa na odstránenie jazykových bariér organizujú základné a rozširujúce jazykové kurzy štátneho jazyka.

S integračnými procesmi cudzincov súvisí uplatňovanie ich práv, zavádzanie uplatňovania tzv. integračného mainstreamingu (s prihliadnutím na špecifiká právneho postavenia žien, maloletých, zdravotne postihnutých a prestarlých migrantov) do prípravy a tvorby legislatívy, vytváraní rezortných politík, právnych predpisov v kontexte na dopad týchto opatrení na oblast' integrácie migrantov. ${ }^{19} \mathrm{Z}$ hl'adiska súčasnej právnej úpravy okrem už uvádzaného základného zákona - Ústavy, a zákona o azyle, či zákona o pobyte cudzincov, je realizácia d’alších práv predmetom viacerých zákonov, ktoré upravujú vybrané spoločenské vzt’ahy jednotlivých oblastí. Možno spomenút' nasledovné:

- Zákon č. 311/2001 Z. z. Zákonník práce v znení neskorších predpisov;

- Zákon č. 5/2004 Z. z. o službách zamestnanosti a o zmene a doplnení niektorých zákonov v znení neskorších predpisov;

- Zákon č. 576/2004 Z. z. o zdravotnej starostlivosti, službách súvisiacich s poskytovaním zdravotnej starostlivosti a o zmene a doplnení niektorých zákonov;

- Zákon č. 443/2010 Z. z. o dotáciách na rozvoj bývania a o sociálnom bývaní;

- Zákon č. 417/2013 Z. z. o pomoci v hmotnej núdzi a o zmene a doplnení niektorých zákonov v znení neskorších predpisov;

- Zákon č. 305/2005 Z. z. o sociálnoprávnej ochrane detí a sociálnej kuratele a o zmene a doplnení niektorých zákonov;

- Zákon č. 36/2005 Z. z. o rodine a o zmene a doplnení niektorých zákonov;

- Zákon č. 448/2008 Z. z. o sociálnych službách a o zmene a doplnení zákona č. 455/1991 Zb. o živnostenskom podnikaní (živnostenský zákon) v znení neskorších predpisov;

- Zákon č. 245/2008 Z. z. o výchove a vzdelávaní (školský zákon) a o zmene a doplnení niektorých zákonov v znení neskorších predpisov;

- Zákon č. 422/2015 Z. z. o uznávaní dokladov o vzdelaní a o uznávaní odborných kvalifikácií a o zmene a doplnení niektorých zákonov.

19 Migračná politika Slovenskej republiky s výhl’adom do roku 2020, s. 4. 
Cudzinci sa môžu istou mierou podiel'at' aj na politickom živote krajiny, najmä v oblasti komunálnej a regionálnej politiky. Už samotná ústava priznáva každému napr. petičné právo, zhromažd'ovacie právo, združovacie právo; cudzincom s trvalým pobytom na území SR volebné právo do orgánov územnej samosprávy. Od roku 2001 majú cudzinci s trvalým pobytom na území SR možnost' volit' a byt' volení do orgánov obce a samosprávneho kraja. Vychádzajúc aj zo zásady zakotvenej v medzinárodných dokumentoch - zákaz diskriminácie, významným je aj zákon č. 365/2004 Z. z. o rovnakom zaobchádzaní v niektorých oblastiach a o ochrane pred diskrimináciou a o zmene a doplnení niektorých zákonov (antidiskriminačný zákon) v znení neskorších predpisov.

Závažnost' problematiky migrantov podčiarkuje Európska únia vytvorením jednotnej integračnej politiky pre členské štáty EÚ, s dôrazom na transparentnost' systému, zníženie administratívnej náročnosti, posilnenie zodpovednosti zúčastnených strán, pracovno-právnu ochranu migrantov a posilnenie integračných opatrení, v kontexte na budúci vývoj národného hospodárstva a demografický vývoj. Pochopitel’ne, vstup Slovenskej republiky do Európskej únie ovplyvnil aj azylovú legislatívu, ale aj jej d’alšie smerovanie - vytvorenie Spoločného európskeho azylového systému (CEAS). Európska komisia spustila program zameraný na zamestnávanie migrantov s názvom „Európsky dialóg na schopnostiach a migrácii“‘. Program je zameraný na utečencov a imigrantov s legálnym pobytom na území EÚ. Fond pre azyl, migráciu a integráciu na roky 2014-2020 bol zriadený Nariadením Európskeho parlamentu a Rady (EÚ) č. 516/2014. Slovenská republika plne podporuje všetky aktivity smerujúce k vytvoreniu spoločného azylového systému Európskej únie, s dôrazom na využitie skúseností jednotlivých členských krajín. Tento systém však súčasne rešpektuje právo každej členskej krajiny rozhodovat' o podmienkach udel'ovania medzinárodnej ochrany cudzincom samostatne. Migračná politika Slovenskej republiky rešpektuje tradičné piliere azylovej politiky a zároveň podporuje i nové formy poskytovania ochrany nadväzujúce na nové výzvy medzinárodného spoločenstva.

Nasledujúca tabul'ka poskytuje prehl'ad udelenia ochrany cudzincom v Slovenskej republike, ako aj udelenie štátneho občianstva SR.

\begin{tabular}{|c|c|c|c|c|c|c|}
\hline ROK & $\begin{array}{c}\text { Počet } \\
\text { žiadostí } \\
\text { o udelenie } \\
\text { azylu }\end{array}$ & $\begin{array}{c}\text { Udelený } \\
\text { azyl }\end{array}$ & $\begin{array}{c}\text { Neudelený } \\
\text { azyl }\end{array}$ & $\begin{array}{c}\text { Poskytnutá/ } \\
\text { neposkytnutá } \\
\text { doplnková } \\
\text { ochrana }\end{array}$ & $\begin{array}{c}\text { Zastavené } \\
\text { konania }\end{array}$ & $\begin{array}{c}\text { Udelené } \\
\text { štátne } \\
\text { občianstvo }\end{array}$ \\
\hline 1993 & 96 & 41 & 20 & & 25 & 0 \\
\hline 1994 & 140 & 58 & 32 & & 65 & 0 \\
\hline 1995 & 359 & 80 & 57 & & 190 & 0 \\
\hline 1996 & 415 & 72 & 62 & & 193 & 4 \\
\hline 1997 & 645 & 69 & 84 & & 539 & 14 \\
\hline 1998 & 506 & 53 & 36 & & 224 & 22 \\
\hline 1999 & 1320 & 26 & 176 & & 1034 & 2 \\
\hline 2000 & 1556 & 11 & 123 & & 1366 & 0 \\
\hline
\end{tabular}




\begin{tabular}{|r|r|r|r|r|r|r|}
\hline 2001 & 8151 & 18 & 130 & & 6154 & 11 \\
\hline 2002 & 9743 & 20 & 309 & & 8053 & 59 \\
\hline 2003 & 10358 & 11 & 531 & & 10656 & 42 \\
\hline 2004 & 11395 & 15 & 1592 & & 11782 & 20 \\
\hline 2005 & 3549 & 25 & 827 & & 2930 & 2 \\
\hline 2006 & 2849 & 8 & 861 & & 1940 & 5 \\
\hline 2007 & 2642 & 14 & 1177 & $82 / 646$ & 1693 & 18 \\
\hline 2008 & 909 & 22 & 416 & $66 / 273$ & 457 & 4 \\
\hline 2009 & 822 & 14 & 330 & $98 / 165$ & 460 & 1 \\
\hline 2010 & 541 & 15 & 180 & $57 / 101$ & 361 & 3 \\
\hline 2011 & 491 & 12 & 186 & $91 / 47$ & 270 & 7 \\
\hline 2012 & 732 & 32 & 334 & $104 / 153$ & 383 & 0 \\
\hline 2013 & 441 & 15 & 124 & $34 / 49$ & 352 & 7 \\
\hline 2014 & 331 & 14 & 197 & $99 / 41$ & 163 & 12 \\
\hline 2015 & 330 & 8 & 124 & $41 / 24$ & 148 & 5 \\
\hline 2016 & 146 & 167 & 82 & $12 / 13$ & 35 & 3 \\
\hline 2017 & 148 & 18 & 70 & $22 / 16$ & 67 & 5 \\
\hline Spolu & $\mathbf{5 8 6 1 5}$ & $\mathbf{8 3 8}$ & $\mathbf{8 0 6 0}$ & $\mathbf{7 0 6 / 1 5 2 8}$ & $\mathbf{4 9 5 4 0}$ & $\mathbf{2 4 6}$ \\
\hline
\end{tabular}

Zdroj: MV SR, Migračný úrad MV SR.

Integrácia cudzincov je zdíhavý a náročný proces, ktorý vyžaduje aktívnu účast' a spoluprácu viacerých subjektov: štátu, organizácií, obcí, ale aj jednotlivcov a samotných cudzincov. Úspešná integrácia zohráva dôležitú úlohu v rozvoji Slovenskej republiky, a tak je náležitá existencia strategického dokumentu s vytýčenými princípmi integračnej politiky. Integrácia súvisí s migráciou, pričom riadený proces integrácie integračná politika vychádza z Migračnej politiky SR. Ochrana základných práv a slobôd je prvoradou úlohou štátu, a v prípade migrantov ide o marginalizovanú skupinu, ktorá vyžaduje osobitnú garanciu práv a slobôd, v podobe efektívnej právnej úpravy. Práva migrantov, utečencov, azylantov sú predmetom medzinárodnej úpravy, pričom postavenie cudzincov upravuje predovšetkým vnútroštátne právo predstavované konkrétnymi zákonmi. Tzv. cudzinecké právo predstavuje najmä zákon o pobyte cudzincov a zákon o azyle.

Vzhl'adom na rozsiahlost' problematiky, pozornost' bola $\mathrm{v}$ príspevku upriamená na niektoré vybrané, základné aspekty, a nebolo možné venovat' sa všetkým atribútom. Dané otázky predmetnej témy zostávajú aj nad’alej prioritou jednotlivých štátov, ako aj Európskej únie.

doc. JUDr. Klaudia Marczyová, PhD.

Akadémia Policajného zboru v Bratislave

klaudia.marczyova@minv.sk 